\title{
Temporal variation in the levels of polycyclic aromatic hydrocarbons (PAHs) off the Galician Coast after the 'Prestige' oil spill
}

\author{
Óscar Nieto ${ }^{1, *}$, Janire Aboigor ${ }^{1}$, Raquel Buján ${ }^{1}$, Momar N'Diaye ${ }^{1}$, Jesús Graña ${ }^{1}$, \\ Liliana Saco-Álvarez ${ }^{2}$, Ángeles Franco ${ }^{3}$, José Antonio Soriano ${ }^{3}$, Ricardo Beiras ${ }^{2}$ \\ ${ }^{1}$ Departamento de Química Analítica e Alimentaria, Universidade de Vigo, 36200 Vigo, Spain \\ ${ }^{2}$ Departamento de Ecoloxía e Bioloxía Animal, Facultade de Ciencias do Mar, Universidade de Vigo, 36200 Vigo, Spain \\ ${ }^{3}$ Instituto Español de Oceanografía, Cabo Estay, Canido, 36200 Vigo, Spain
}

\begin{abstract}
We studied the temporal variation of polycyclic aromatic hydrocarbons (PAH) levels in the wild mussel Mytilus galloprovincialis, water and sediment from 3 sampling sites on the Galician coast of Spain between the rias of Arousa and Muros, which were dramatically affected by the large oil spill from the oil tanker 'Prestige'. The samples were collected periodically, from November 22, 2002, 3 d after the tanker sank, until December 23, 2003. The total hydrocarbon content in the water and sediment samples was determined by fluorescence and expressed as concentration of chrysene. In addition, individual PAHs - analytes recommended by the US Environmental Protection Agency - were analysed in the mussel samples by HPLC using fluorimetric detection. A maximum concentration of $2.07 \times 10^{3} \mathrm{\mu g}$ equiv. of chrysene $\mathrm{l}^{-1}$ was found in the water column at the sampling site of Furnas on November 29, 2002 which decreased to $0.21 \mu \mathrm{g} \mathrm{l}^{-1}$ by October 2003. Likewise, the concentrations of the sum of the 16 PAHs determined in the mussel samples collected at the sampling points were between $2.5 \times 10^{3}$ and $5.9 \times 10^{3} \mathrm{ug} \mathrm{kg}^{-1}$ dry weight in the days immediately following the oil spill and then decreased to $0.13 \times 10^{3} \mu \mathrm{kg}^{-1}$ in October 2003. However, no relevant information could be obtained from the PAH content of the sediment samples. A relation between parent PAHs accumulated in the mussels and their molecular weight (MW) has been found to provide an indication of hydrocarbon pollution. A good approximation was obtained when the total PAH content $(\Sigma \mathrm{PAH})$ was represented versus the ratio of low MW PAHs to high MW PAHs ( $\mathrm{LPAH}: \Sigma H P A H)$. When the depuration rate $r$ of individual PAHs by the mussels was fitted to an exponential model, 2 different values of $r$ were found depending on the PAH concentration. The change from a slow to fast depuration rate was produced when the logarithm of the concentration was 1.0.
\end{abstract}

KEY WORDS: 'Prestige' oil spill $\cdot$ PAH analysis $\cdot$ Mytilus $\cdot$ Mussels $\cdot$ Temporal variation

Resale or republication not permitted without written consent of the publisher

\section{INTRODUCTION}

On November 13, 2002 the oil tanker 'Prestige', carrying $77000 \mathrm{t}$ of heavy fuel, started leaking through a $15 \mathrm{~m}$ crack in the hull while the tanker was being towed. It broke apart $6 \mathrm{~d}$ later and sank to $3700 \mathrm{~m}$. An estimated $50000 \mathrm{t}$ of fuel were spilled, according to local press reports. On November 16 the oil slick reached the coast of Spain, affecting a coastline zone between cape Corrubedo and Ferrol. We started sampling a small area near cape Corrubedo, between the rias of Muros and Arousa. Water, sediments and mussel Mytilus galloprovincialis samples were collected in order to determine the impact of the fuel on the coastal ecosystem. During the first days of December 2002 a second black tide, originating from the tanker when its hull broke into 2 pieces, reached the southern Galician coast. This affected one station we had previously considered as unpolluted.

Polycyclic aromatic hydrocarbons (PAHs) are ubiquitous components in the marine environment. They are among the compounds included in the Oslo and Paris 
(OSPAR) Commission List of Chemicals for Priority Action and the EU Water Framework Directive List of Priority Hazardous Substances. In addition, the US Environmental Protection Agency (USEPA) has identified 16 PAHs as priority pollutants. PAHs originating at high temperatures (combustion) are dominated by the parent species, while the crude oils contain a wide range of alkyl derivatives. Several tanker accidents have occurred off the Galician coast before that of the 'Prestige', and include the 'Andros Fortune' (1961), the 'Polycommander' (1970), the 'Urquiola' (1976), the 'Andros Patria' (1979) and the 'Aegean Sea' (1992); however, studies on PAHs were only performed after the last one (Sole et al. 1996, Albaiges et al. 2000, Porte et al. 2000a,b, Pastor et al. 2001). The heavy fuel that spilled from the 'Prestige' contained a complex fraction of aromatic hydrocarbons. This mixture included low molecular weight aromatic hydrocarbons, such as naphthalene and their alkyl derivatives, and high molecular weight aromatic compounds, but in a lesser proportion (Bayona et al. 2004 p. 13-20). We monitored the concentrations of PAHs in samples taken concurrently of seawater, sediment and the mussel Mytilus galloprovincialis in order to evaluate the impact of the 'Prestige' oil spill in a representative stretch of the affected coastline and follow the recovery during the first year after the spill. Depuration rates of individual PAHs as a function of their molecular weight and their bioaccumulation levels were also investigated.

\section{MATERIALS AND METHODS}

Sampling stations. Samples of water, sediment and non-commercial wild populations of the mussel Mytilus galloprovincialis (40-60 mm length) were collected from 3 sampling stations in an exposed strip off the Galician coast in northwestern Spain (Fig. 1): (1) a narrow sandy creek (M1; $\left.42^{\circ} 38^{\prime} 38^{\prime \prime} \mathrm{N}, 9^{\circ} 02^{\prime} 15^{\prime \prime} \mathrm{W}\right)$, (2) a long sandy beach (M2; $\left.42^{\circ} 33^{\prime} 05^{\prime \prime} \mathrm{N}, 9^{\circ} 01^{\prime} 40^{\prime \prime} \mathrm{W}\right)$, and (3) a rocky shore $\left(\mathrm{M} 3 ; 42^{\circ} 30^{\prime} 59^{\prime \prime} \mathrm{N}, 9^{\circ} 01^{\prime} 00^{\prime \prime} \mathrm{W}\right)$. On the first sampling date (November 22, 2002), the fuel oil slick had reached M1 but not M2 nor M3; on the second sampling date (December 17, 2002) the fuel had already reached all 3 sites. We sampled every $2 \mathrm{wk}$ between December 2002 and February 2003, and every 2 mo afterwards. The number of mussels collected ranged between 200 and 400 depending on their availability, date and site. Multiple water and sediment samples were taken from the sampling stations and then pooled into composite samples for analysis.

Reagents. Stock solutions of $5 \mathrm{mg} \mathrm{l}^{-1}$ of the following hydrocarbons in acetonitrile were prepared without previous purification: (1) benz[a]anthracene and benzo[b]fluoranthene (Supelco); (2) naphthalene, acenaph-

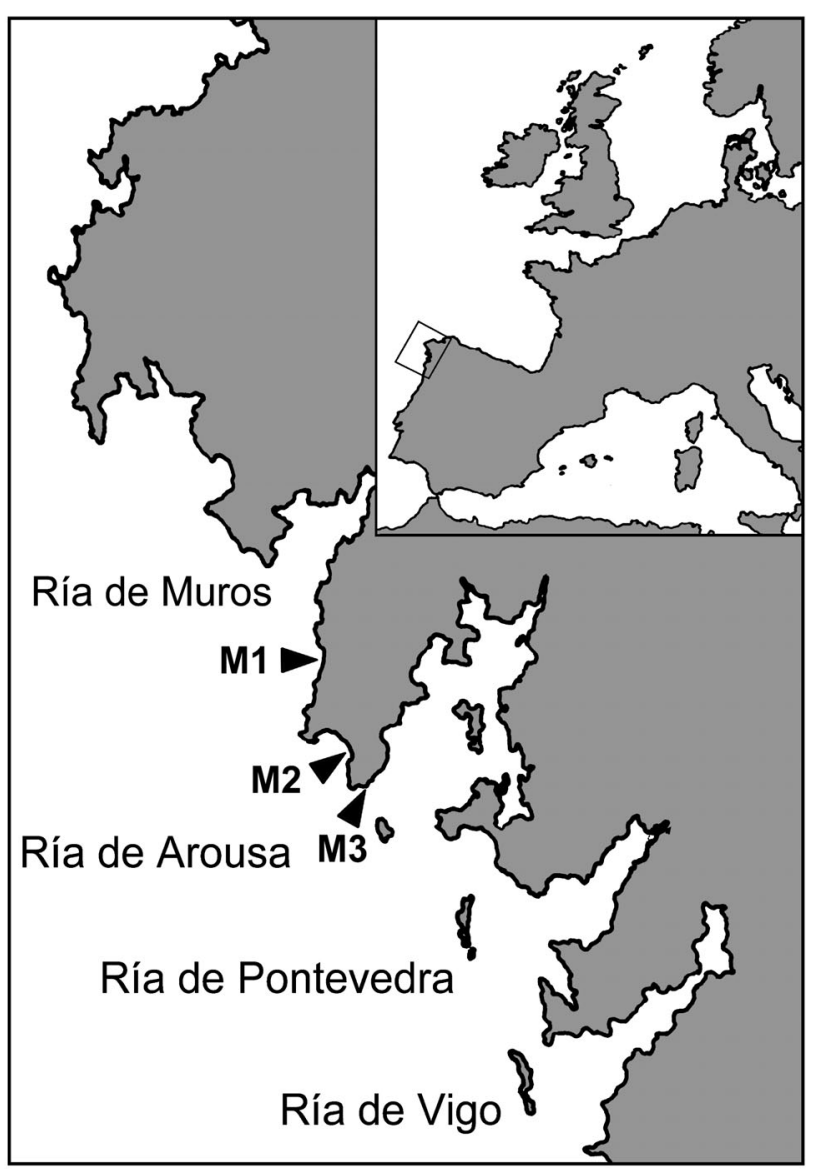

Fig. 1. Location of the water, sediment and mussel sampling stations (M1, M2, M3) in the Galician rías (northwestern Iberian Peninsula)

thene, fluorene, phenanthrene, chrysene, benzo[e]pyrene, benzo[k]fluoranthene and benzo[g,h,i]perylene (Fluka); (3) anthracene and indeno[1,2,3-c,d]pyrene (Riedel de Haën); (4) fluoranthene, pyrene and benzo[a]pyrene (Sigma); and (5) dibenz[a,h]anthracene (Aldrich). From those solutions, subsequent dilutions were prepared for HPLC calibration. We used 2methylchrysene (Dr. Ehrenstorfer) as an internal standard. All reagents and solvents were of HPLC and analytical grade quality.

Apparatus. The analysis of PAHs by HPLC was carried out using a chromatographic system model Alliance 2690 (Waters), equipped with a Vydac 201TP54 column $(4.6 \times 250 \mathrm{~mm}, 5 \mu \mathrm{m}$ particle size; Grace Vydac) and coupled to a fluorimetric detector model 474 (Waters). All experimental conditions for recording the chromatogram and the data acquisition from the detector were controlled with the software Millenium 32 (Waters). A water-jacket (Altech) maintained a constant column temperature during the elution process. The sediment and the soft tissue of the 
mussel samples were freeze-dried using a model Alpha 1-4 (Martin Christ). A spectrofluorometer model RF-1501 (Shimadzu) was used for the determination of the total content of hydrocarbons in the samples of water, sediments and mussels.

Condition index. The condition index was calculated on samples of 15 mussels per site as dry weight to length ratio $\left(\mathrm{g} \mathrm{m}^{-1}\right)$. Electronic callipers were used to measure the length of mussels.

Chemical analysis. The water samples were collected in 21 amber glass bottles. The water was poured into a separatory funnel, 3 liquid-liquid extractions with dichloromethane were carried out, and the organic phases obtained (USEPA 1980; Method 3510B). After substitution of the solvent by n-hexane, the total hydrocarbon content was determined by fluorimetry at fixed excitation and emission wavelengths of 310 and $360 \mathrm{~nm}$, respectively. The fluorescence intensity was compared with standard solutions of chrysene in n-hexane as well as with solutions of naturally aged oil from the tanker 'Prestige'.

The hydrocarbons from sediment and mussel (40 to $60 \mathrm{~mm}$ length) samples were extracted for $7 \mathrm{~h}$ by means of a soxhlet system that used a mixture of $n$ hexane and acetone as solvents. Then, a solid phase extraction clean up of the extract was carried out with a $10 \%$ deactivated alumina column and n-hexane. Subsequently, the eluate obtained from sediment samples was determined by fluorimetry under the same conditions as the water samples, and the PAHs obtained from the mussel tissue samples were determined by HPLC with fluorimetric detection.

We injected $20 \mu$ of sample into the column and a gradient elution was performed by using water and methanol as eluents (López et al. 1996, Viñas 2002). The column temperature was maintained at a constant $23.5^{\circ} \mathrm{C}$. These measurement conditions allow the separation of the PAHs with good resolution, although recording the chromatogram takes about $60 \mathrm{~min}$. Nevertheless, these conditions avoid erroneous measurements due to the presence of interferences. The fluorimetric detection was carried out by programming the specific excitation and emission wavelengths of each PAH analysed.

The analytical data were verified through the participation in an intercalibration exercise organised by the Spanish Institute for Oceanography (IEO). The reference material was wet mussel tissue and was the same as that used in the last intercalibration exercise organised by Quality Assurance of Information for Marine Environmental Monitoring in Europe. Satisfactory results were obtained $(|z|<2)$. Subsequent analyses of that reference material were used as internal quality assurance.

Statistical methods. The decrease in PAH concentration in the mussels was fitted to the following equation:

$$
C_{t}=C_{0}{ }^{(-r t)} \exp (-r t)
$$

where $C_{0}$ is the maximum concentration found in the mussel, $C_{t}$ is the concentration of a hydrocarbon at a given time $t$, and $r$ is the depuration rate for each individual PAH.

Condition index data were analysed by ANOVA and an a posteriori Tukey test.

\section{RESULTS AND DISCUSSION}

\section{Sample characterisation}

Table 1 shows the location and general environmental variables of the surface water and sediment for the 3 sampling sites. Salinity, $\mathrm{pH}$ and dissolved oxygen (DO) were typical of oceanic water. Sampling site M3 had the highest $5 \mathrm{~d}$ biological oxygen demand $\left(\mathrm{BOD}_{5}\right)$, whereas hydrocarbon levels in the water (see next section) were the lowest. Thus, this variable as it related to general organic pollution was not useful for monitoring the fuel contamination. At sites M1 and M2 the bottom was sandy, poor in organic content and well oxygenated, conditions that minimize the persistence of hydrocarbons (Marchand \& Caprais 1981).

Table 1. Locations and physical and chemical variables recorded at the 3 sampling sites M1, M2 and M3 (see Fig. 1). For surface water the range of annual variation is shown with maximum values of temperature (T) found in August. Surface salinity (S) and $\mathrm{pH}$ were reduced in rainy conditions. $\mathrm{BOD}_{5}: 5 \mathrm{~d}$ biological oxygen demand; DO: dissolved oxygen. Sand data were collected on November 29, 2002 (mean $\pm \mathrm{SD}_{;} \mathrm{n}=3$ ). Eh: redox potential; OM: organic matter content

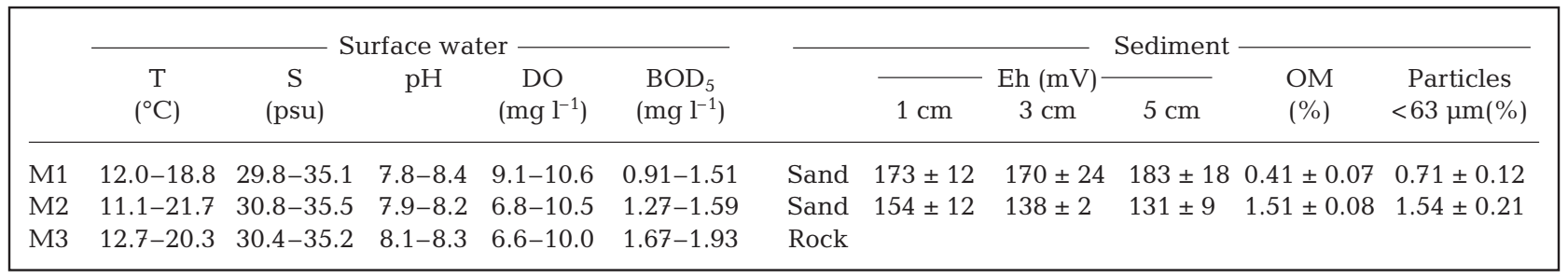




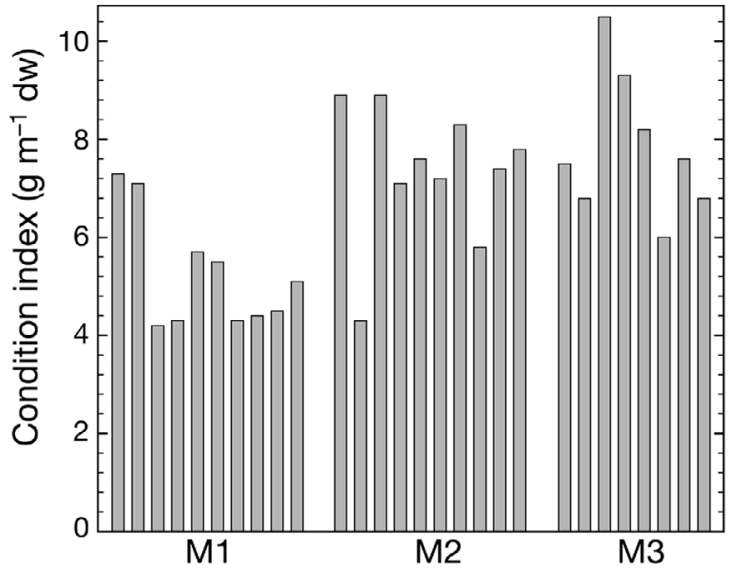

Fig. 2. Condition indices obtained for the mussel samples at each station. For each station the bars follow in chronological order (dw = dry weight)

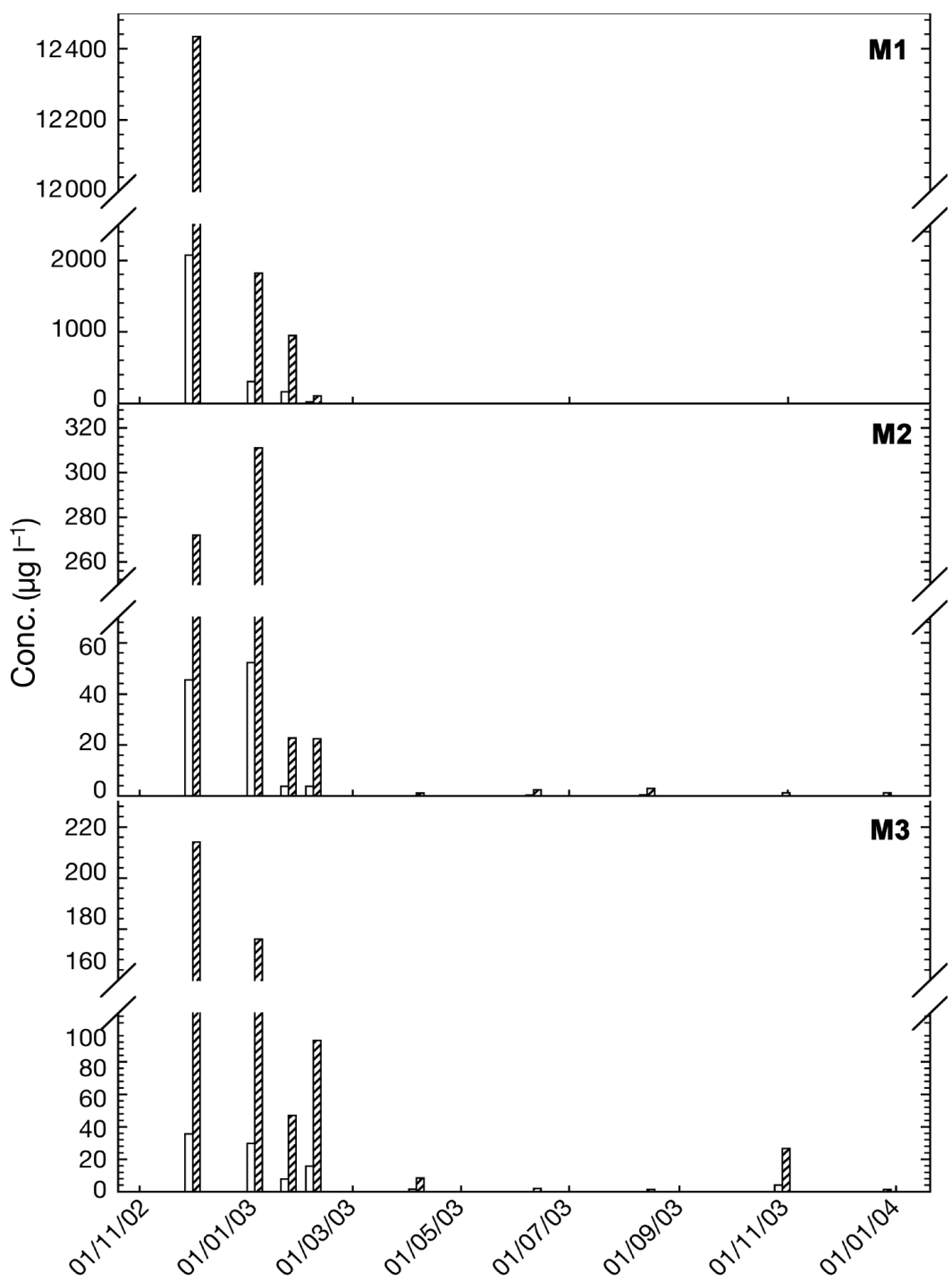

Fig. 3. Variation of the total hydrocarbon concentration (conc.) found in the water samples over time. White bars: $\mu \mathrm{g}$ equiv. of chrysene $\mathrm{I}^{-1}$; hatched bars: $\mu \mathrm{g}$ equiv. of fuel $\mathrm{l}^{-1}$. Dates given as $\mathrm{dd} / \mathrm{mm} / \mathrm{yy}$
Fig. 2 shows the condition index observed for the mussels collected at each sampling station. The lowest indices were found in the samples collected at M1, which received the impact of 2 oil spills. No statistically significant differences in condition index were found between M2 and M3 ( $p>0.05)$.

\section{Hydrocarbon fate in water and sediments}

\section{Water}

The total hydrocarbon concentrations found at the 3 sampling stations versus time are represented in Fig. 3. The highest concentrations were found on the first day samples were collected. A maximum value of $2.07 \times 10^{3} \mu \mathrm{g}$ equiv. of chrysene $\mathrm{l}^{-1}\left(12.4 \times 10^{3} \mu \mathrm{g}\right.$ equiv. of fuel $\mathrm{l}^{-1}$ ) at M1 and $45.4 \mu \mathrm{g}$ equiv. of chrysene $\mathrm{l}^{-1}$ (272 $\mu \mathrm{g}$ equiv. of fuel $\mathrm{l}^{-1}$ ) at M2 were obtained on November 29. Likewise, a maximum concentration of $29.8 \mu \mathrm{g}$ equiv. of chrysene $\mathrm{l}^{-1}$ (176 $\mu \mathrm{g}$ equiv. of fuel $\mathrm{l}^{-1}$ ) was found at M3 on January 3, 2003. The maximum concentrations found at the sampling stations M2 and M3 were similar to those observed in Prince William Sound, Alaska after the 'Exxon Valdez' oil spill (Neff \& Stubblefield 1995) or in Point Judith Pond, New York after the 'North Cape' oil spill (Reddy \& Quinn 2001). However, the maximum concentrations detected in the water samples at M1 were higher than those reported in the references cited above. Stn M2 was chosen as an apparently unpolluted zone on November 21, 2002 because it was not visibly affected by the first oil spill, but on the first sampling day the water samples contained high concentrations of hydrocarbons. Although these concentrations increased after the second oil slick affected that zone, they rapidly declined during the following days. From April 4, 2003 onwards, values ranged between 1.43 and $0.18 \mu \mathrm{g}$ equiv. of chrysene $\mathrm{l}^{-1}$ (8.48 and $1.21 \mu \mathrm{g}$ equiv. of fuel $\left.\mathrm{l}^{-1}\right)$. These concentrations are considered background levels in other studies (Maldonado et al. 1999, Telli-Karakoç et al. 2002). 


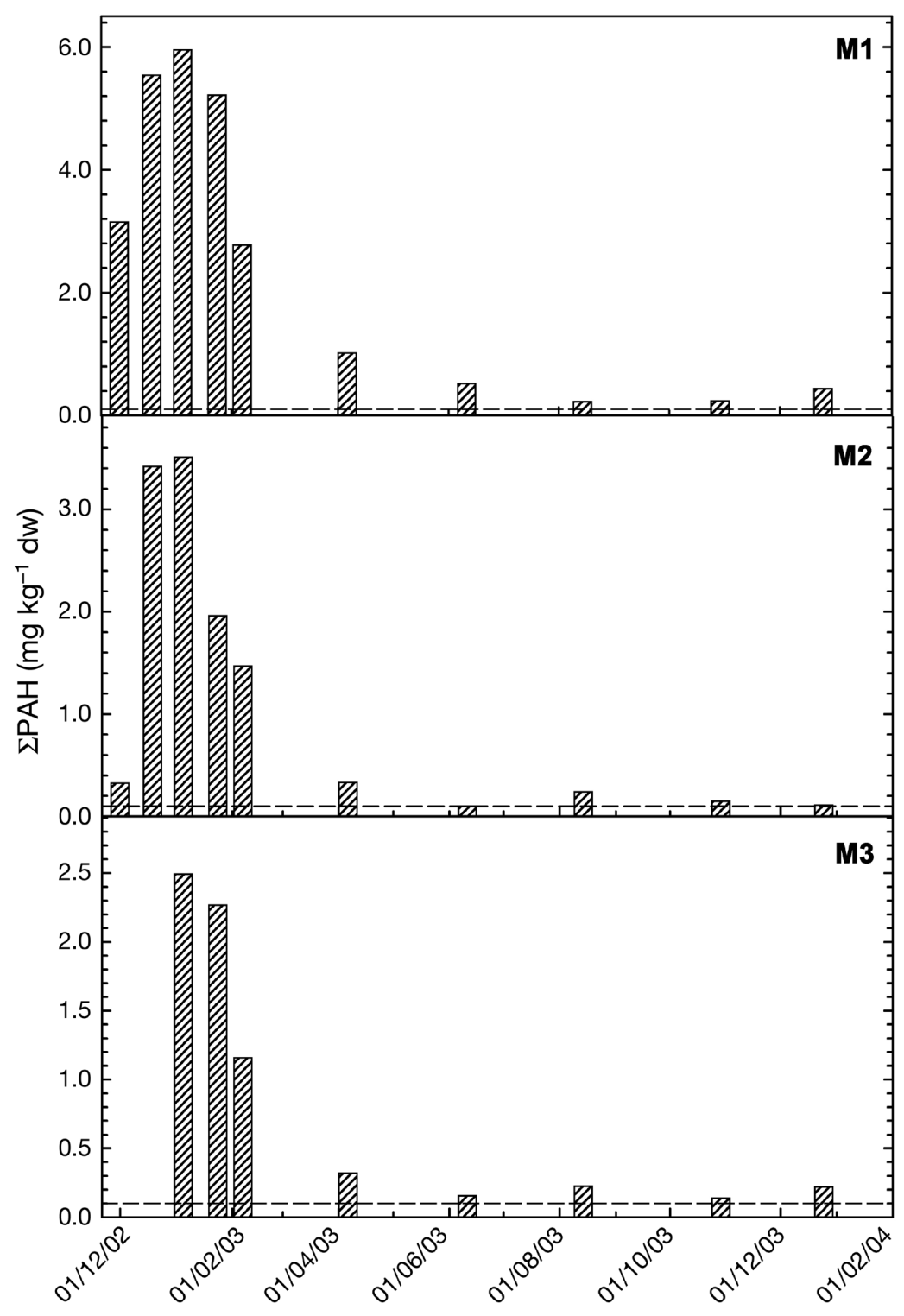

Fig. 4. Variation of the total hydrocarbon concentration ( $\Sigma \mathrm{PAH}$, except naphthalene, acenaphthene and fluorene) in mussel samples over time. Dashed line: background values. Dates given as dd/mm/yy

\section{Sediments}

Sample sediments from M1 and M2 were sandy with the percentage of particles $<63 \mu \mathrm{m}$ in size being $0.71 \pm 0.12 \%$ (mean $\pm \mathrm{SE}$ ) and $1.54 \pm 0.21 \%$, respectively. Similarly, the percentage of organic matter in sediments from M1 and M2 was $0.41 \pm 0.07 \%$ and $1.51 \pm 0.08 \%$, respectively. As a result very little adsorption of hydrocarbons occurred. No trend was observed in concentration of hydrocarbons with time. A maximum concentration of $4.7 \mu \mathrm{g}$ equiv. of chrysene $\mathrm{kg}^{-1}$ (25.9 $\mu \mathrm{g}$ equiv. of fuel $\mathrm{kg}^{-1}$ dry weight) was found at M2 on August 12, 2003 and a minimum con- centration of $0.8 \mu \mathrm{g}$ equiv. of chrysene $\mathrm{kg}^{-1}$ (4.9 $\mu \mathrm{g}$ equiv. of fuel $\mathrm{kg}^{-1}$ dry weight) was detected on M1 at October 27, 2003.

\section{Determination of PAHs in mussel samples by HPLC}

The sum of the concentrations of individual PAHs determined by HPLC in the mussels over time is represented in Fig. 4. This graphic does not include the variation of concentrations with time of naphthalene, acenaphthene and fluorene because they are markedly different to the rest of the parent PAHs. Between November 2002 and June 2003 the concentrations found at M1 were higher than at M2, and the latter higher than at M3 for all the samples collected. The hydrocarbon contents found at M1 were very high from the first sampling day and a maximum value of about $5.9 \mathrm{mg} \mathrm{kg}^{-1}$ dry weight was detected on January 3, 2003. The concentrations found during the period November 2002 to June 2003 were higher than those previously reported (Boehm et al. 1996, Baumard et al. 1998, 1999, Porte et al. 2000a) except for one case after the 'Exxon Valdez' oil spill (about $8 \times 10^{3} \mu \mathrm{g} \mathrm{kg}^{-1}$ dry weight; see Carls et al. 2001). In the beginning, M2 was chosen as an apparently unpolluted area and the concentration of PAHs found in November 2002 supported that assumption $\left(0.3 \times 10^{3} \mu \mathrm{g}\right.$ $\mathrm{kg}^{-1}$ dry weight), despite the high hydrocarbon content detected in the seawater. However, there was a drastic increase in PAH levels in mussels to a maximum concentration in January 2003 of $3.5 \mathrm{mg}$ $\mathrm{kg}^{-1}$ dry weight after the second oil slick reached the coast. Rapid incorporation of PAHs into the mussel Mytilus edulis has been previously demonstrated (Wolfe et al. 1981, Widdows et al. 1982). Moreover, the maximum amount of hydrocarbons was found at Stn M3 on January 3, the first day of sampling in 2003.

We used a reference value for an unpolluted area $\left(0.1 \times 10^{3} \mu \mathrm{g} \mathrm{kg}^{-1}\right.$ dry weight $)$ obtained in a previous study (Ó. Nieto et al. unpubl. data) from mussels collected close to the mouth of the ría of Pontevedra in February 2002. In all cases, the concentrations declined to near background values, but in some cases 
those concentrations remained above, from April to June 2003 and onwards. An exponential decrease in hydrocarbon concentrations has been observed in depuration studies in the laboratory (Farrington et al. 1982). An increase in the burden of hydrocarbons was observed in the samples collected at Stns M1 and M3 in December 2003, probably as a consequence of the remobilization of the fuel deposited on the sea bed because of bad weather during the previous weeks.

The percentage of each parent $\mathrm{PAH}$ determined in the mussels is represented in Fig. 5 for the 3 sampling stations. Two distinct time periods have been determined according to the results observed above: from November 2002 to April 2003 and from June to December 2003. In the first period, as expected, the profiles were almost identical at the 3 sampling stations because the pollution was from a single source. The predominant compounds were chrysene and benzo[e] pyrene. In the second period, different profiles in the proportion of parent PAHs were observed. Phenanthrene, fluoranthene and pyrene were the predominant hydrocarbons, whereas those with higher molecular weight were found in lesser proportions. Bearing in mind that a decrease in $\mathrm{PAH}$ concentrations occurred from January to April and the percentage of parent PAHs was very similar in that period, it follows that the decrease in the concentration of each parent $\mathrm{PAH}$ occurred at the same rate.

In studies on marine and coastal pollution by PAHs, special emphasis is put on the ratios between particular hydrocarbons, such as phenanthrene: anthracene, fluoranthene:pyrene and benzo[e]pyrene:benzo[a]pyrene indices, in order to determine the origin of the contamination (see reviews in Baumard et al. 1999 and De Luca et al. 2004). In this case no uncertainty exists about the source of hydrocarbons, but a relationship between parent PAHs has been determined in order to test the degree of hydrocarbon pollution. A good approximation was reported by De Luca et al. (2004) where the total PAH content $(\Sigma \mathrm{PAH})$ is plotted against the $\Sigma$ LPAH: $\Sigma$ HPAH ratio ( $\Sigma$ LPAH $=$ naphthalene + acenaphthene + fluorene + phenanthrene + anthracene, and $\Sigma \mathrm{H}$ -
$\mathrm{PAH}=$ fluoranthene + pyrene + benz[a]anthracene + chrysene + benzo[b]fluoranthene + benzo[k]fluoranthene + benzo[e]pyrene + benzo[a] pyrene + ben$\mathrm{zo}[\mathrm{g}, \mathrm{h}, \mathrm{i}]$ perylene + dibenz[a,h]anthracene + indeno[1,2,3-c,d]pyrene). The results obtained are shown in Fig. 6 and all the points in the plot can be fitted to the following exponential equation $(\mathrm{r}=0.89)$ :

$$
\Sigma \mathrm{PAH}=6.82 \exp (-6.51 \Sigma \mathrm{LPAH}: \Sigma \mathrm{HPAH})
$$

In addition, most of the points can be gathered into 2 well defined areas of the plot. The points for which $\Sigma \mathrm{PAH}>0.8 \mathrm{mg} \mathrm{kg}^{-1}$ (dry weight) and $\Sigma \mathrm{LPAH}: \Sigma \mathrm{HPAH}$ 


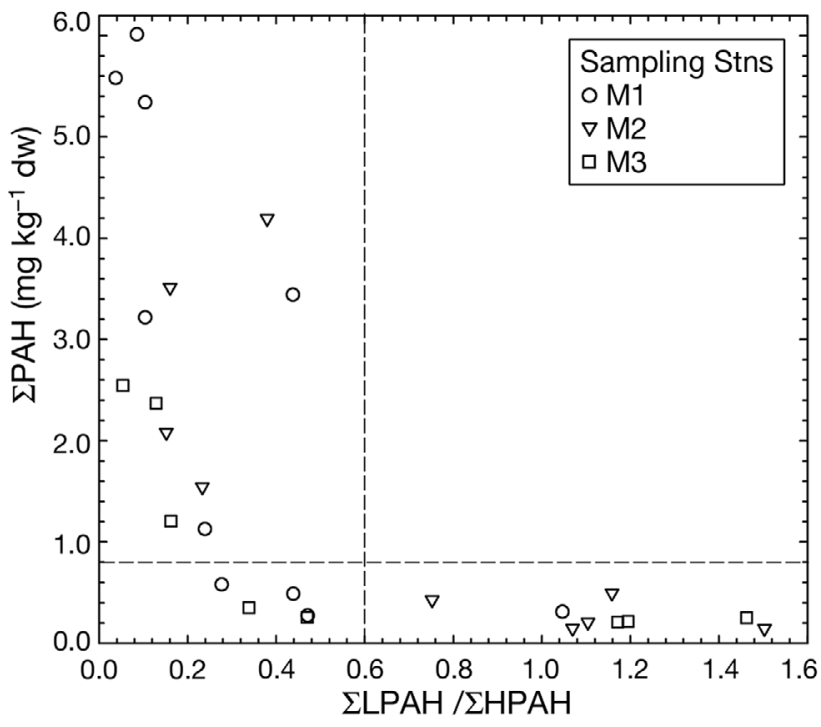

Fig. 6. Plot of the total PAH content in mussels ( $\mathrm{PAH})$ versus the $\Sigma$ LPAH: $\Sigma$ HPAH ratio. The hydrocarbons used for the sum of $\Sigma$ PAH, $\Sigma$ LPAH and $\Sigma$ HPAH are described in the text

$<0.6$ correspond to the mussel samples collected at the 3 sampling stations during November 2002 to April 2003. However, the points for which the total content of PAHs is $<0.8 \mathrm{mg} \mathrm{kg}^{-1}$ dry weight and a $\Sigma$ LPAH: $\Sigma$ HPAH ratio is $>0.6$ correspond to the mussels collected from June 2003 onwards. Hence, these limits, which are similar to those proposed by De Luca et al. (1999), can be considered as a good index to distinguish between a polluted and unpolluted zone.

Five points from all the results obtained are located in an intermediate zone where $\Sigma \mathrm{PAH}$ and $\Sigma \mathrm{LPAH}: \Sigma \mathrm{HPAH}$ are $<0.8 \mathrm{mg} \mathrm{kg}^{-1}$ and <0.6, respectively. They can be considered as alert values indicating light levels of pollution or the remobilization of fuel deposited on the seabed.

The recommendations from the Spanish Agency for Food Safety, following those of the World Health Organization (WHO 1991), indicate that the sum of the parent PAHs (benzo[k]fluoranthene + benz[a] anthracene + benzo[b]fluoranthene + benzo[a]pyrene + dibenz[a,h] anthracene + indeno[1,2,3-c,d]pyrene) should be lower than $0.2 \times 10^{3} \mu \mathrm{gg}^{-1}$ dry weight. Fig. 7 shows the concentration of these hydrocarbons over time, which has a similar pattern to that in Fig. 4. The maximum concentrations at the 3 sampling stations were found in December 2002 and January 2003 and they declined to below the recommended limits in April 2003.

\section{Depuration rate}

Several experiments have been carried out to better understand the depuration of hydrocarbons in marine organisms. As Figs. 4 \& 7 show, the decreases in the hydrocarbon concentrations with time follow an exponential curve that can be adjusted to the following equation (Farrington et al. 1982):

$$
C_{t}=C_{0}^{(-r t)}
$$

where $C_{t}$ is the concentration of a parent hydrocarbon detected at each sampling station at a given time $t(\mathrm{~d})$; $C_{0}$ is the maximum concentration of that hydrocarbon detected at this sampling station (both expressed as ng $\mathrm{g}^{-1}$ dry weight) and $r$ is the depuration rate.

The values of $r$ obtained for some parent PAHs at each sampling station are shown in Table 2. The depuration rate of some hydrocarbons were not cal-

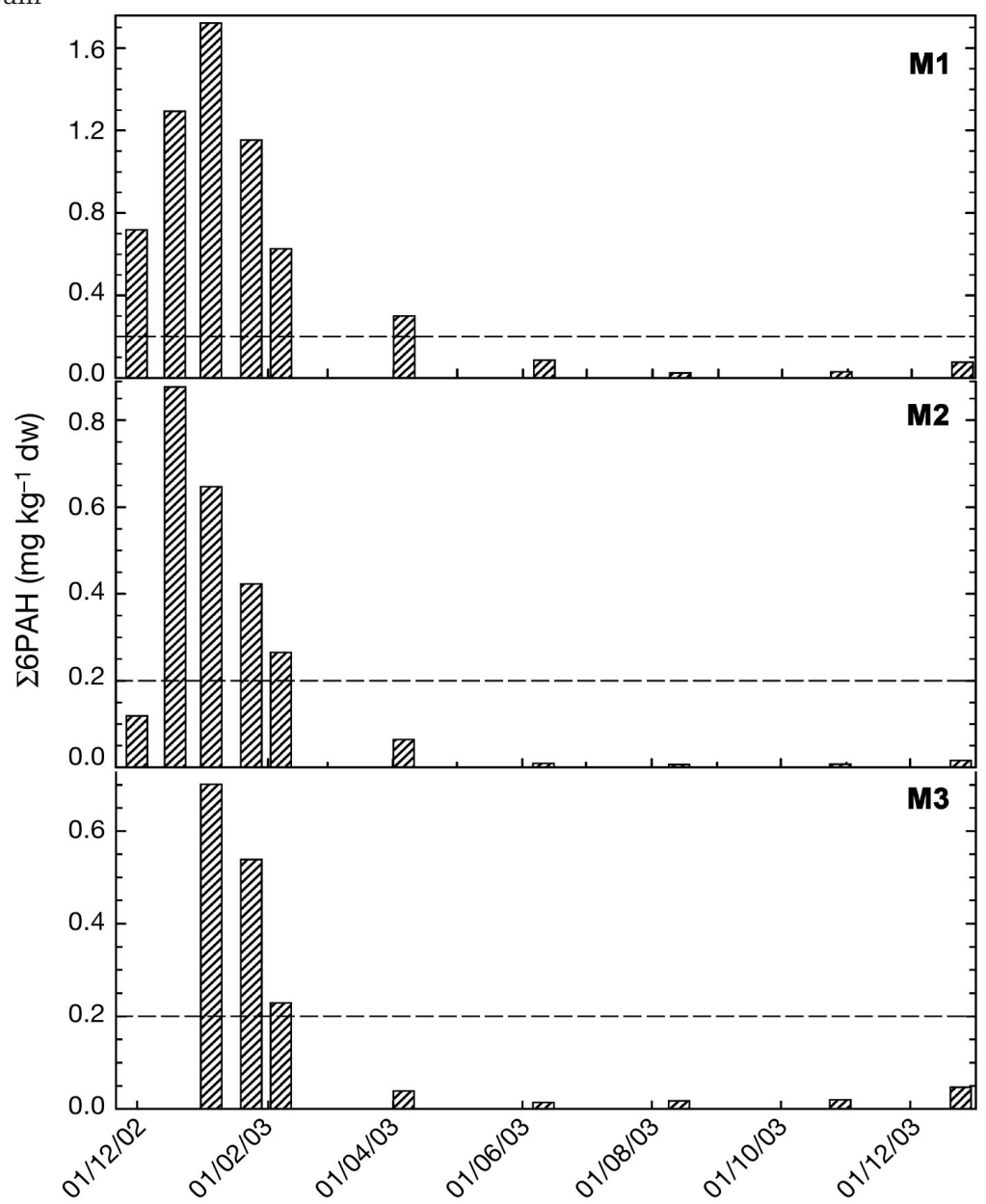

Fig. 7. Variation of the sum of 6 PAHs (benzo[k]fluoranthene + benz[a]anthracene + benzo[b]fluoranthene + benzo[a]pyrene + dibenz[a,h]anthracene + indeno[1,2,3-c,d]pyrene) in mussels over time. Dashed line: maximum concentration $\left(0.2 \times 10^{3} \mathrm{\mu g} \mathrm{kg}^{-1}\right.$ dry weight $)$ allowed in seafood by the Spanish Agencyfor Food Safety. Dates given as dd/mm/yy 
Table 2. Depuration rates $\left(\mathrm{d}^{-1}\right)$ in mussels obtained for each parent PAH at the 3 sampling stations studied. A sampling station with 2 values given for a $\mathrm{PAH}$ indicates those with first and second phase depuration rates

\begin{tabular}{|lccc|}
\hline & M1 & M2 & M3 \\
\hline Anthracene & 0.0047 & $0.0120 / 0.0009$ & 0.0023 \\
Fluoranthene & 0.0070 & 0.0019 & 0.0006 \\
Pyrene & $0.0099 / 0.0030$ & 0.0006 & $0.0088 / 0.0003$ \\
Benz[a]anthracene & $0.0121 / 0.0028$ & $0.0218 / 0.0035$ & $0.0162 / 0.0021$ \\
Chrysene & $0.0145 / 0.0039$ & $0.0194 / 0.0019$ & 0.0100 \\
Benzo[e]pyrene & $0.0080 / 0.0020$ & $0.0108 / 0.0022$ & $0.0104 / 0.0022$ \\
Benzo[b]fluoranthene & $0.0084 / 0.0027$ & 0.0064 & $0.0119 / 0.0045$ \\
Benzo[k]fluoranthene & $0.0120 / 0.0021$ & $0.0157 / 0.0001$ & 0.0038 \\
Benzo[a]pyrene & $0.0174 / 0.0018$ & $0.0115 / 0.0026$ & $0.0130 / 0.0011$ \\
Dibenz[a,h]anthracene & 0.0139 & 0.0056 & 0.0236 \\
& & & \\
\hline
\end{tabular}

culated because either their concentrations did not follow a variation with time similar to those represented in Fig. 4 (such as acenaphthene, fluorene, naphthalene and phenanthrene) or were not detected on the dates that the samples were collected (benzo[g,h,i]perylene and indeno[1,2,3-c,d]pyrene). In most cases the data showed 2 phases of depuration with different slopes. A first phase of fast depuration (from January 2003 to April 2003) had values ranging from 0.0218 to $0.0080 \mathrm{~d}^{-1}$, and a second phase (from June 2003 onwards) had depuration rates of 0.0001 and $0.0045 \mathrm{~d}^{-1}$. The change in depuration rate is produced when the logarithm of the concentration $C_{t}$ is between 1.0 and 1.5. Consequently, these results suggest the existence of 2 depuration mechanisms for all the hydrocarbons that do not depend on their nature, but on their concentrations. These findings agree with previous studies of the depuration of PAHs in other bivalves (Rantamäki 1997, Hwang et al. 2004).

In conclusion, the massive fuel oil spillage from the oil tanker 'Prestige' caused elevated aromatic hydrocarbon concentrations in coastal seawater in the order of the $2.07 \times 10^{3} \mu \mathrm{g}$ equiv. of chrysene $\mathrm{l}^{-1}$ during the first days after the spill. This was reflected in a peak in $\mathrm{PAH}$ accumulation in mussels a few weeks after that in seawater. Afterwards, depuration followed an exponential pattern independent of PAH molecular weight, but the depuration rate seemed to decrease when total PAH concentration decreased to $<0.2 \times 10^{3} \mu \mathrm{kg}^{-1}$ dry weight. During the following winter, there was a slight increase in hydrocarbon concentrations as a consequence of subtidal remobilization during winter storms, and PAH levels in mussels remained above background levels 1 yr later. In contrast, the hydrocarbon concentrations in the sandy sediment did not follow any consistent geographical or even temporal pattern within the 1 yr study.
Acknowledgements. The authors thank the Ministerio de Ciencia y Tecnología (project VEM 2003-20068-C05-02) for financial support. The authors also thank Dr. E. Fernández Suárez and the rest of the Laboratorio Ecología Marina research group for material support and collaboration in sampling campaigns. M.N'D. thanks the Spanish Ministry of Foreign Affairs for the AECI programme grant support. The manuscript has benefited from the suggestions of 2 anonymous reviewers.

\section{LITERATURE CITED}

Albaiges J, Porte C, Pastor D, Biosca X, Sole $M(2000)$ The integrated use of chemical and biochemical markers for assessing the effects of the Aegean Sea oil spill in the Galicia coast (NW Spain). Water Stud Ser 8:73-84

Baumard P, Budzinski H, Garrigues P (1998) PAHs in Arcachon Bay, France: origin and biomonitoring with caged organisms. Mar Pollut Bull 36:577-586

Baumard P, Budzinski H, Garrigues P, Dizer H, Hansen PD (1999) Polycyclic aromatic hydrocarbons in recent sediments and mussels (Mytilus edulis) from the Western Baltic Sea: occurrence, bioavailability and seasonal variations. Mar Environ Res 47:17-47

Bayona JM, Albaigés J, Diez S, Alzaga R, and 9 others (2004) Plan de intervención científica sobre el vertido y hundimiento del buque Prestige. CSIC, IEO, Universidade da Coruña

Boehm PD, Mankewicz PJ, Hartung R, Neff JM, Page DS, Gilfillan ES, O'Reilly JE, Parker KR (1996) Characterization of mussel beds with residual oil and the risk to foraging wildlife 4 years after the 'Exxon Valdez' oil spill. Environ Toxicol Chem 15:1289-1303

Carls MG, Badcock MM, Harris PM, Irvine GV, Cusick JA, Rice SD (2001) Persistence of oiling in mussel beds after the Exxon Valdez oil spill. Mar Environ Res 51:167-190

De Luca G, Furesi A, Leardi R, Micera G, Panzanelli A, Piu PC, Sanna G (2004) Polycyclic aromatic hydrocarbons assessment in the sediments of the Porto Torres Harbor (Northern Sardinia, Italy). Mar Chem 86:15-32

Farrington JW, Davis AC, Frew NM, Rabin KS (1982) No. 2 fuel oil compounds in Mytilus edulis. Retention and release after an oil spill. Mar Biol 66:15-26

Hwang HM, Wade TL, Sericano JL (2004) Destabilized lysosomes and elimination of polycyclic aromatic hydrocarbons and polychlorinated biphenyls in eastern oysters (Crassostrea virginica). Environ Toxicol Chem 23: 1991-1995

López D, Rubio S, Polo LM (1996) Quantitation of polycyclic aromatic hydrocarbons in urban air particulate by HPLC with programmed flourescence detection. Quim Anal 15: $224-229$

Maldonado C, Bayona JM, Bodineau L (1999) Sources, distribution and water column processes of aliphatic and polycyclic aromatic hydrocarbons in the northwest Black Sea. Environ Sci Technol 33:2693-2702

Marchand M, Caprais MP (1981) Suivi de la pollution de l'Amoco Cadiz dans l'eau de mer et les sédiments marins. In: Amoco Cadiz. Conséquences d'une pollution accidentelle par les hydrocarbures. Centre Nationale pour l'Exploitation des Océans, Paris, p 23-54

Neff JM, Stubbefield WA (1995) Chemical and toxicological 
evaluation of water quality following the Exxon Valdez Oil Spill. In: Wells PG, Butler JN, Hughes JS (eds) Exxon Valdez oil spill: fate and effects in Alaskan waters. American Society for Testing and Materials, Philadelphia, PA, p 141-177

Pastor D, Sanchez J, Porte C, Albaiges J (2001) The Aegean Sea oil spill in the Galicia Coast (NW Spain). I. Distribution and fate of the crude oil and combustion products in subtidal sediments. Mar Pollut Bull 42:895-904

Porte C, Biosca X, Pastor D, Sole M, Albaiges J (2000a) The Aegean Sea oil spill. 2. Temporal study of the hydrocarbons accumulation in bivalves. Environ Sci Technol 34: 5067-5075

Porte C, Biosca X, Sole M, Albaiges J (2000b) The Aegean Sea oil spill on the Galician Coast (NW Spain). III: The assessment of long-term sublethal effects on mussels. Biomarkers 5:436-446

Rantamäki P (1997) Release and retention of selected polycyclic aromatic hydrocarbons (PAH) and their methylated derivatives by the common mussel (Mytilus edulis) in the brackish water of the Baltic Sea. Chemosphere 35:487-502

Reddy CM, Quinn JG (2001) The North Cape oil spill. Hydrocarbons in Rhode Island coastal waters and Point Judith Pond. Mar Environ Res 52:445-461

Sole M, Porte C, Biosca X, Mitchelmore CL, Chipman JK, Livingstone DR, Albaiges J (1996) Effects of the 'Aegean Sea' oil spill on biotransformation enzymes, oxidative stress and DNA-adducts in digestive gland of the mussel (Mytilus edulis L.). Comp Biochem Physiol C Comp Pharmacol 113:257-265

Editorial responsibility: Otto Kinne (Editor-in-Chief), Oldendorf/Luhe, Germany
Telli-Karakoç F, Tolun I, Henkelmann B, Klimm C, Okay O, Schramm KW (2002) Polycyclic aromatic hydrocarbons (PAHs) and polychlorinated biphenyls (PCBs) distributions in the bay of Marmara Sea: Izmit Bay. Environ Pollut 119:383-397

USEPA (1980) Test methods for evaluating solid waste: physical/chemical methods. The official EPA, 1st edn. EPA SW-846, US Environmental Protection Agency, Washington, DC

Viñas L (2002) Evaluación de hidrocarburos aromáticos policíclicos (HAPs) por cromatografía líquida de alta eficacia (CLAE) en el entorno marino gallego. PhD thesis, Universidade de Vigo

WHO (1991) Evaluation of certain food additives and contaminants. In: Thirty-seventh report of the Joint FAO/WHO Expert Committee on Food Additives. WHO Tech Rep Ser 806, Geneva, p 27-29

Widdows J, Phelps DK, Galloway W (1980) Measurement of physiological condition of mussels transplanted along a pollution gradient in Narragansett Bay. Mar Environ Res 4:181-194

Wolfe DA, Clark RC, Foster CA, Hawkes JW, Macleod WD (1981) Hydrocarbon accumulation and histopathology in bivalve molluscs transplanted to the Baie de Morlaix and the rade de Brest. In: Amoco Cadiz (ed) Fates and effects of the oil spill. Proceeding of the International Symposium, Centre Oceanologique de Bretagne, Brest, November 19-22, 1979. Centre Nationale pour l'Exploitation des Oceans, Paris, p 599-616

Submitted: February 11, 2005; Accepted: February 6, 2006 Proofs received from author(s): December 12, 2006 